\title{
In vitro Evaluation of Various Bioagents against Detected Seed Mycoflora of Groundnut
}

\author{
R.P. Bhosale , K.D. Navgire, K.A. Rewale and S.M. Wahul \\ Department of Plant Pathology, College of agriculture, Vasantrao Naik Marathwada Krishi \\ Vidyapeeth, Parbhani (MH), India \\ *Corresponding author
}

\begin{tabular}{|l|}
\hline K e y w or d s \\
$\begin{array}{l}\text { Alternaria alternata, } \\
\text { mycoflora, Trichoderma } \\
\text { viride, } T \text {. harzianum, } \\
\text { hamatum }\end{array}$ \\
\hline Article Info \\
\hline $\begin{array}{l}\text { Accepted: } \\
\text { 12 September } 2018 \\
\text { Available Online: } \\
\text { 10 October } 2018\end{array}$ \\
\hline
\end{tabular}

\section{Introduction}

Groundnut (Arachis hypogaea L.), is an annual legume crop, known as peanut, earthnut or monkey-nut. It is one of the $4^{\text {th }}$ most important oilseed crop and $13^{\text {th }}$ most important food crop of the world, being cultivated in more than 100 countries in six continents. Groundnut kernels contain 40-50 per cent fat, 20-50 per cent protein and 10-20
Biotic and abiotic stresses are major constraints in the production of groundnut. Among biotic stresses apart from bacterial and viral diseases, many fungal diseases are of economic importance. The major fungal diseases are Early leaf spot (Cercospora arachidicola), Late leaf spot (Cercosporidium personatum), Rust (Puccinia arachidis), Botrytis blight (Botrytis cinera), Aflarot/Yellow mould (Aspergillus flavus), Damping off (Pythium spp.), Stem and pod rot (Ralstonia solani), collar rot (Aspergillus niger), Charcoal rot (Macrophom inaphaseolina), Anthracnose (Colletotrichum arachidis), Wilt (Fusarium oxysporum), Root rot (Fusarium solani), Stem rot (Sclerotium rolfsii), Damping off (Pythium spp.) and Leaf blight (Alternaria alternata). Among which Yellow mould, Collar rot, Wilt, Damping off and Leaf blight are seed borne which affect groundnut crop. For the management of different mycoflora, effect of nine bio-control agents Alternaria alternate, Aspergillus flavus, Aspergillus niger were observed in vitro condition. The biocontrol agents are Trichoderma viride, T. harzianum, T. koningii, T. hamatum T. virens, T. longibrachitum and T. lignorum along with two bacterial bio-agents P. fluorescens and B. subtilis evaluated in vitro were found antifungal to A. alternata. However, $T$. viride was found most effective with significantly least mycelial growth (5.33 $\mathrm{mm})$ and its highest inhibition $(94.07 \%)$. The second and third best antagonists found were $T$. hamatum and T. koningii, with minimum mycelial growth of $13.33 \mathrm{~mm}$ and 17.12 $\mathrm{mm}$ and inhibition of 85.14 and 80.87 per cent, respectively. per cent carbohydrates and also rich in vitamin $\mathrm{E}$, niacin, riboflavin, thiamine, falacin, calcium, phosphorus, magnesium, zinc, iron and potassium.

The groundnut diseases like late leaf spot caused by Cercosporidium personatum and rust caused by Puccinia arachidis are the most serious fungal diseases worldwide which accounted more than 50 per cent yield losses. 
The late leaf spot disease generally appears at 55 to 60 days after sowing and also causes more than 50 per cent loss in pod and haulm yields in groundnut (Jyosthna et al., 2004). Among collar rot caused by Aspergillus niger was also reported to cause 55 per cent yield loss (Dasgupta et al., 2000). Sclerotinia blight is an important disease of groundnut and the yield loss of 30 to 50 per cent due to Sclerotinia blight (Bowen et al., 2000). During the investigations various experiments were conducted at the Department of Plant Pathology, College of Agriculture, VNMKV, Parbhani.

\section{Materials and Methods}

Seven fungal antagonists viz., Trichoderma viride, T. harzianum, T. koningii, T. hamatum, T. virens, T. longibrachitum, T. lignorum and two bacterial $P$. fluorescens and B. subtlis were evaluated in vitro against Alternaria alternata, Aspergillus flavus and A. niger applying Dual Culture Technique (Dennis and Webster, 1971). Seven days old cultures of the test bio-agents and test fungus (Alternaria alternata, Aspergillus flavus and A. niger) grown on (PDA, NA) were used for the study. Discs (5 mm dia.) of culture growth of the test fungus and bio-agents were cut out with sterilized cork borer. Then two culture discs, one each of the test fungus and bio-agents were placed at equidistance and exactly opposite with each other on solidified PDA medium in Petri plates aseptically and plates were incubated at $26 \pm 2{ }^{\circ} \mathrm{C}$. PDA plates inoculated only with culture discs of the test fungus were maintained as untreated control and all the treatments were replicated thrice.

\section{Experimental details}

Design: CRD (Completely Randomized Design)

Replications: Three

Treatments: Ten

\section{Treatment details}

$\mathrm{T}_{1}$ : Trichoderma viride

$\mathrm{T}_{2}$ : T. harzianum

$\mathrm{T}_{3}:$ T. hamatum

$\mathrm{T}_{4}: T$. koningii

$\mathrm{T}_{5}: T$. longibrachiatum

$\mathrm{T}_{6}: T$. virens

$\mathrm{T}_{7}: T$. lignorum

$\mathrm{T}_{8}$ : Pseudomonas fluorescens

$\mathrm{T}_{9}$ : Bacillus subtilis

$\mathrm{T}_{10}$ : Control (untreated)

Observations on linear mycelial growth of the test pathogen and test bio-agent were recorded at an interval of 24 hours and continued till untreated control plates were fully covered with mycelial growth of the test pathogen. Per cent inhibition of the test pathogen with the test bio-agent over untreated control was calculated by applying following formula (Arora and Upaddhyay, 1978).

Colony growth in control plate Colony growth in intersecting plate

Per cent Growth = X100

Inhibition Colony growth in control plate

\section{Results and Discussion}

\section{Radial mycelial growth / colony diameter of A. alternata}

Results (Table 1, PLATE I and Fig. 1) indicated that all the bio-agents evaluated exhibited antifungal activity against $A$. alternata and significantly inhibited its mycelial growth, over control. Radial mycelial growth of A. alternata was ranged from 5.33 $\mathrm{mm}$ to $55.53 \mathrm{~mm}$ as against control $(90.00$ $\mathrm{mm})$. However, T. viride was found most effective with significantly least mycelial growth $(5.33 \mathrm{~mm})$, these were followed by $T$. hamatum $(13.33 \mathrm{~mm})$, T. koningii $(17.12 \mathrm{~mm})$, T. lignorum $(23.33 \mathrm{~mm})$, T.longibrachitum $(27.94 \mathrm{~mm}), T$. virens $(34.42 \mathrm{~mm}), T$. 
harzianum (34.66 mm), P. fluorescens (46.26 $\mathrm{mm})$ and $B$. subtilis $(55.53 \mathrm{~mm})$, respectively.

Mycelial growth and inhibition of $A$. alternata

Results (Table 1, PLATE I and Fig. 1) indicated that mycelial growth inhibition of $A$. alternata was ranged from 38.07 per cent to 94.07 per cent as against control $(90.00 \mathrm{~mm})$. However, T. viride was found most effective with significantly highest mycelial growth inhibition $(94.07 \%)$, these were followed by T. hamatum (85.14\%), T. koningii $(80.87 \%)$, T. lignorum (74.07 \%), T. longibrachitum (68.95\%), T. virens (62.86\%), T. harzianum (61.48 \%), P. fluorescens (48.60\%) and B. subtilis $(38.07 \%)$.

Radial mycelial growth / colony diameter of A.flavus

Results (Table 2, PLATE II and Fig. 2) indicated that all the bio-agents evaluated exhibited antifungal activity against $A$. flavus and significantly inhibited its mycelial growth over control. Radial mycelial growth of $A$. flavus was ranged from $19.99 \mathrm{~mm}$ to 55.75 $\mathrm{mm}$ as against control $(90.00 \mathrm{~mm})$.

However, T. harzianum was found most effective with significantly least mycelial growth $(19.22 \mathrm{~mm})$, these were followed by $T$. viride $(26.40 \mathrm{~mm}), T$. virens $(30.75 \mathrm{~mm})$, T. longibrachitum $(31.91 \mathrm{~mm})$, T. lignorum (40.56 mm), T. hamatum (43.76 mm), $T$. koningii $(41.93 \mathrm{~mm})$, P. fluorescens $(51.52$ $\mathrm{mm})$ and B. subtilis $(55.75 \mathrm{~mm})$.

\section{Mycelial growth and inhibition of A.flavus}

Results (Table 2, PLATE II and Fig. 2) indicated that mycelial growth inhibition of $A$. flavus was ranged from 38.05 per cent to 77.78 per cent as against control $(90.00 \mathrm{~mm})$. However, T. harzianum was found most effective with significantly highest mycelial growth inhibition $(77.78 \%)$, these were followed by $T$. viride (70.66 \%), T. virens (65.83\%), T. longibrachitum (64.54\%), T. lignorum (54.93\%), T. hamatum (51.37\%), T. koningii (53.41 \%), P. fluorescens (42.75\%) and $B$. subtilis $(38.05 \%)$.

\section{Radial mycelial growth / colony diameter of A. niger}

Results (Table 3, PLATE III and Fig. 3) indicated that all the bio-agents evaluated exhibited antifungal activity against $A$. niger and significantly inhibited its mycelial growth over control. Radial mycelial growth of $A$. niger was ranged from $21.85 \mathrm{~mm}$ to $55.55 \mathrm{~mm}$ as against control $(90.00 \mathrm{~mm})$. However, $T$. harzianum was found most effective with significantly least mycelial growth (21.85 $\mathrm{mm}$ ), these were followed by T. viride (28.12 $\mathrm{mm}), T$. virens $(31.42 \mathrm{~mm}), T$. longibrachitum (32.40), T. lignorum (41.05 mm), T. hamatum $(44.62 \mathrm{~mm}), \quad T$. koningii $(44.99 \mathrm{~mm}), P$. fluorescens $(52.35 \mathrm{~mm})$ and B. subtilis $(55.55$ $\mathrm{mm})$.

\section{Mycelial growth and inhibition of A.niger}

Results (Table 3, PLATE III and Fig. 3) indicated that mycelial growth inhibition of $A$. niger was ranged from 38.28 per cent to 75.72 per cent as against control $(90.00 \mathrm{~mm})$. However, T. harzianum was found most effective with significantly highest mycelial growth inhibition $(75.72 \%)$, these were followed by $T$. viride $(68.76 \%), T$. virens (67.31\%), T. longibrachitum (64.00\%), T. lignorum (54.39\%), T. hamatum (50.42\%), T. koningii (50.01\%), P. fluorescens (45.17\%) and $B$. subtilis (38.28\%).

Result (Table 1) revealed that bioagents tested were found effective against $A$. alternataand significantly inhibited its mycelial growth, over control. 
Table.1 In vitro efficacy of bioagents against $A$. alternate

\begin{tabular}{|c|c|c|c|}
\hline Tr. No. & Treatments & $\begin{array}{l}\text { Colony Dia.of test } \\
\text { pathogen } *(\mathrm{~mm})\end{array}$ & $\begin{array}{l}\text { Per cent } \\
\text { Inhibition }\end{array}$ \\
\hline $\mathrm{T}_{1}$ & Trichoderma viride & 5.33 & $\begin{array}{c}94.07 \\
(75.90)\end{array}$ \\
\hline $\mathbf{T}_{2}$ & T. harzianum & 34.66 & $\begin{array}{c}61.48 \\
(51.63)\end{array}$ \\
\hline$\overline{T_{3}}$ & T. koningii & 17.12 & $\begin{array}{c}80.87 \\
(64.06) \\
\end{array}$ \\
\hline $\mathrm{T}_{4}$ & T. hamatum & 13.33 & $\begin{array}{c}85.14 \\
(67.32)\end{array}$ \\
\hline $\mathbf{T}_{5}$ & T. virens & 34.42 & $\begin{array}{c}62.86 \\
(52.45)\end{array}$ \\
\hline $\mathrm{T}_{6}$ & T. longibrachiatum & 27.94 & $\begin{array}{c}68.95 \\
(56.13)\end{array}$ \\
\hline $\mathbf{T}_{7}$ & T. lignorum & 23.33 & $\begin{array}{c}74.07 \\
(59.38) \\
\end{array}$ \\
\hline $\mathrm{T}_{8}$ & Pseudomonas fluorescence & 46.26 & $\begin{array}{c}48.60 \\
(43.89)\end{array}$ \\
\hline $\mathbf{T}_{9}$ & Bacillus subtilis & 55.53 & $\begin{array}{c}38.07 \\
(38.09) \\
\end{array}$ \\
\hline$\overline{T_{10}}$ & Control & 90.00 & $\begin{array}{c}0.00 \\
(0.00)\end{array}$ \\
\hline & SEm \pm & 0.38 & 0.41 \\
\hline & C.D.@1\% & 1.26 & 1.35 \\
\hline
\end{tabular}

* Mean of three replication, figures in Parentheses are arc sine transformed values

Table.2 In vitro efficacy of bioagents against A.flavus

\begin{tabular}{|c|c|c|c|}
\hline Tr. No. & Treatments & $\begin{array}{l}\text { Colony Dia. of test } \\
\text { pathogen } *(\mathrm{~mm})\end{array}$ & $\begin{array}{l}\% \text { mycelial } \\
\text { Inhibition }\end{array}$ \\
\hline $\mathbf{T}_{1}$ & T. viride & 26.40 & $\begin{array}{c}70.66 \\
(57.20)\end{array}$ \\
\hline $\mathbf{T}_{2}$ & T. harzianum & 19.99 & $\begin{array}{c}77.78 \\
(61.88)\end{array}$ \\
\hline $\mathbf{T}_{\mathbf{3}}$ & T. koningii & 41.93 & $\begin{array}{c}53.41 \\
(46.96)\end{array}$ \\
\hline$\overline{T_{4}}$ & T. hamatum & 43.76 & $\begin{array}{l}51.37 \\
(45.79)\end{array}$ \\
\hline$\overline{T_{5}}$ & T. virens & 30.75 & $\begin{array}{c}65.83 \\
(54.23)\end{array}$ \\
\hline$\overline{T_{6}}$ & T. longibrachiatum & 31.91 & $\begin{array}{c}64.54 \\
(53.45)\end{array}$ \\
\hline $\mathbf{T}_{7}$ & T. lignorum & 40.56 & $\begin{array}{c}54.93 \\
(47.83)\end{array}$ \\
\hline $\mathbf{T}_{8}$ & Psudomonas fluorescens & 51.52 & $\begin{array}{l}42.75 \\
(40.83)\end{array}$ \\
\hline $\mathrm{T}_{9}$ & Bacillus subtilis & 55.75 & $\begin{array}{l}38.05 \\
(38.09)\end{array}$ \\
\hline $\mathrm{T}_{10}$ & Control & 90.00 & $\begin{array}{l}0.00 \\
(0.00)\end{array}$ \\
\hline & SEm \pm & 0.37 & 0.41 \\
\hline & C.D.@1\% & 1.21 & 1.36 \\
\hline
\end{tabular}

*Mean of three replications, figures in Parentheses are arc sine transformed values 
Table.3 In vitro efficacy of bioagents against $A$. niger

\begin{tabular}{|c|c|c|c|}
\hline Tr. No. & Treatments & $\begin{array}{l}\text { Colony Dia.of test } \\
\text { pathogen } *(\mathrm{~mm})\end{array}$ & $\begin{array}{l}\% \text { mycelial } \\
\text { Inhibition }\end{array}$ \\
\hline $\mathrm{T}_{1}$ & T. viride & 28.12 & $\begin{array}{c}68.76 \\
(56.01) \\
\end{array}$ \\
\hline $\mathbf{T}_{2}$ & T. harzianum & 21.85 & $\begin{array}{c}75.72 \\
(60.48)\end{array}$ \\
\hline$\overline{T_{3}}$ & T. koningii & 44.99 & $\begin{array}{c}50.01 \\
(45.01) \\
\end{array}$ \\
\hline $\mathbf{T}_{4}$ & T. hamatum & 44.62 & $\begin{array}{c}50.42 \\
(45.24)\end{array}$ \\
\hline $\mathbf{T}_{5}$ & T. virens & 31.42 & $\begin{array}{c}67.31 \\
(55.13) \\
\end{array}$ \\
\hline$\overline{T_{6}}$ & T. longibrachiatum & 32.40 & $\begin{array}{c}64.00 \\
(53.13)\end{array}$ \\
\hline $\mathbf{T}_{7}$ & T. lignorum & 41.05 & $\begin{array}{c}54.39 \\
(47.52)\end{array}$ \\
\hline $\mathrm{T}_{8}$ & Psudomonas fluorescens & 52.35 & $\begin{array}{l}45.17 \\
(42.22)\end{array}$ \\
\hline$\overline{T_{9}}$ & Bacillus subtilis & 55.55 & $\begin{array}{l}38.28 \\
(38.22)\end{array}$ \\
\hline$T_{10}$ & Control & 90.00 & $\begin{array}{c}0.00 \\
(0.00)\end{array}$ \\
\hline & $\mathrm{SEm} \pm$ & 0.32 & 0.36 \\
\hline & C.D.@1\% & 1.08 & 1.20 \\
\hline
\end{tabular}

*Mean of three replications, figures in parenthesis arc sine transformed values.

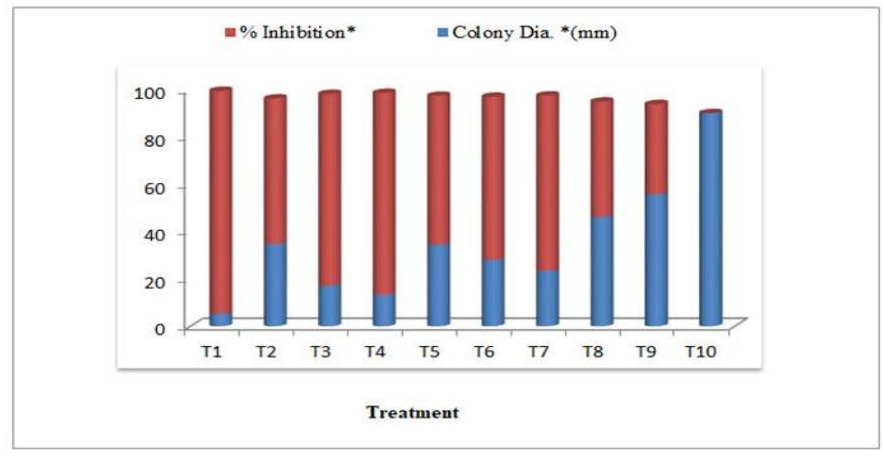

Fig. 1 In vitro efficacy of bio-agents (A. alternata)

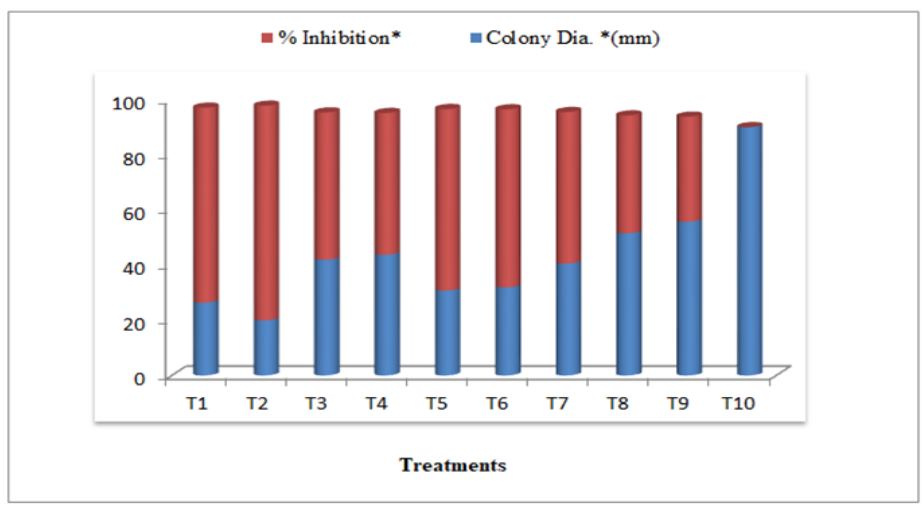

Fig. 2 In vitro efficacy of bio-agents (A. flavus) 


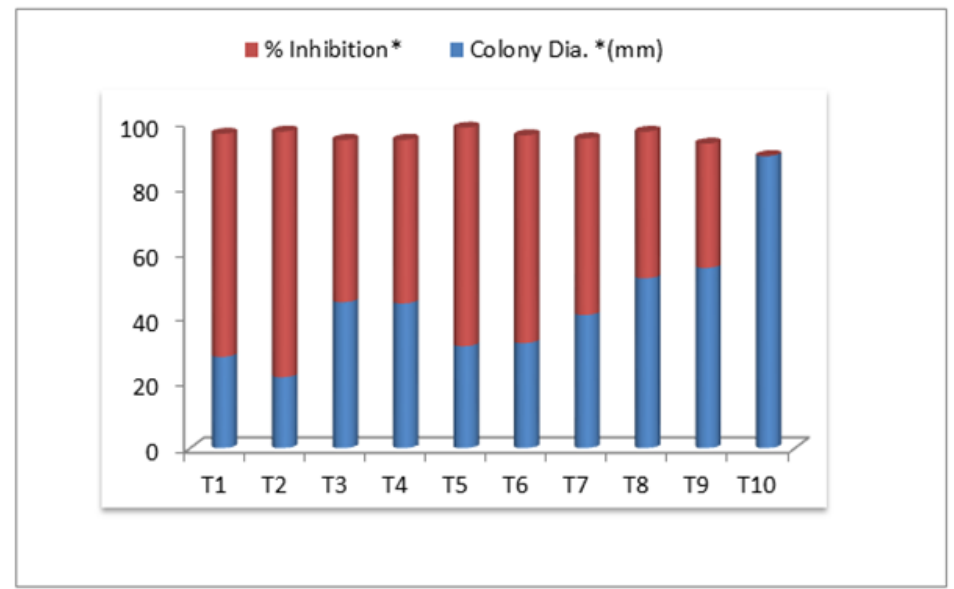

Fig. 3 In vitro efficacy of bio-agents (A. niger)

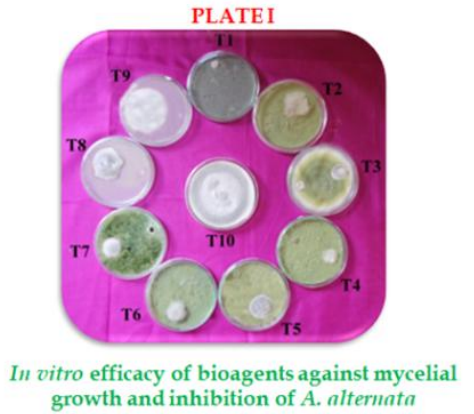
growth and inhibition of $A$. alternata

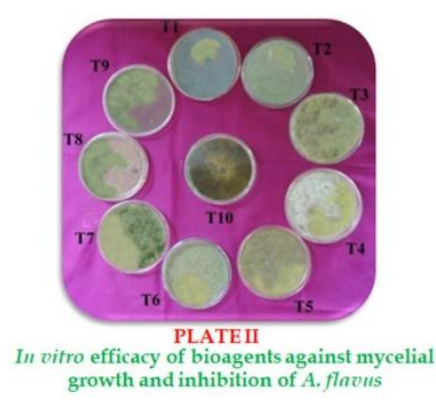

growth and inhibition of $A$. flavus

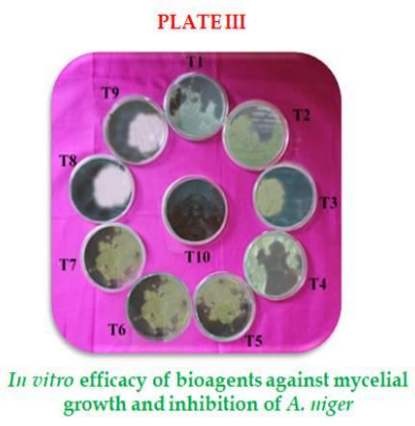

Fungal bioagents viz., T. viride, T. hamatum and $T$. koningii were reported efficient antagonists against $A$. alternata, these results were in agreement with the finding of several workers. Similar result were reported on other crops like onion by Wanggikar et al., (2014) and Mishra et al., (2012), in safflower by Taware et al., (2014), in sesame by Lubaina et al., (2014) and Bharathi et al., (2013) and in cotton by Ramegowda et al., (2007).

Result (Table 2) revealed that all bioagent tested were found effective against A. flavus and significantly inhibited its mycelial growth, over control. Fungal bioagents viz., $T$. harzianum, $T$. viride and $T$. virenswere reported efficient antagonists against $A$. flavus these results were in agreement with the finding of several workers. Studies on similar line were reported on groundnut and other crops like rice, black gram, Pennisetum americanum, sesame and cowpea by Johnson et al., (2008); Halgekar et al., (2014); Bhushan et al., (2014); Ashwini et al., (2014); Bharathi et al., (2013) and by Agarwal et al., (2011).

Result (Table 3) revealed that all the bioagents tested were found effective against A. niger and significantly inhibited its mycelial growth, over control. Fungal bioagents viz., T. harzianum, $T$. viride and $T$. virens were reported efficient antagonists against $A$. niger and these results were in agreement with the finding of several workers viz., Johnson et al., (2008), Agarwal et al., (2011), Gajera et al., (2011) and Rakholiya et $a l$. , (2010) and in other crops like rice reported by Halgekar et al., (2014); Pennisetum americanum by Bhushan et al., (2014); black gram by Ashwini et al., (2014) and sesame by Bharathi et al., (2013). 


\section{References}

Agarwal, T., Malhotra, A., Biyani, M. and Trivedi, P. C. (2011) In vitro interaction of Trichoderma isolates against Aspergillus niger, Chaetomium spp. and Penicillium spp. Indian J. Fund. Appl. Life Sci., 1 (3): 125-128.

Ashwini, C., Giri, G. K. and Halgekar, N. Y. (2014) Efficacy of bio-agents against seed borne fungi of black gram. Int. $J$. Appl. Biol. Pharma. Tech., 5 (3).

Bharathi, V., Sudhakar, R., Parimala, K. and Reddy, V. A. (2013) Evaluation of bioagents and biofertilizers for the management of seed and seedling diseases of Sesamum indicum (sesame). Sci. J. Pl. Pathol., 2 (03): 179-186.

Bhushan, G., Sharma, S. K., Kumar, S. and Singh, A. P. (2014) Antagonistic effects of Trichoderma against seed-borne fungi of Pennisetum americanum. Ethiopian Int. J. Multidis. Res., 2 (1): 13-19.

Halgekar, N. Y., Giri, G. K. and Ashwini, C. (2014) Efficacy of bioagents against seed borne fungi of rice. Inter. J. of Appl. Biol. and Pharmaceu. Tech., 5 (3):157-158.

Johnson, M., Reddy, N. P. and Reddy, R. (2008) Comparative efficacy of rhizosphere mycoflora, insecticides and herbicides against groundnut stem rot caused by Sclerotium rolfsii. Ann. Pl. Protec. Sci., 16 (2): 414-418.

Lubaina, A. S. and Murugan, K. (2015) Evaluation of biological efficacy of Trichoderma species isolates against Alternaria leaf spot disease of sesame. Inter. J. Appl. Bio. pharma. Tech., 6 (1): $17-24$.

Mishra, R. K. and Gupta, R. P. (2012) In vitro evaluation of plant extracts, bio-agents and fungicides against purple blotch and Stemphylium blight of onion J. Med. Pl. Res., 6 (48): 5840-5843.

Ramegowda, G. Naik, M. K., Sunkad, G., Patil, M. B. and Sataraddi, A. (2007) Evaluation of fungicides, botanicals and bioagents against leaf spot by Alternaria macrospora in cotton. Indian J. Pl. Protec., 35 (2): 316-319.

Taware, M. R., Gholve, V. M. and Day, U. (2014) Bio-efficacy of fungicides, bioagents and plant extracts/botanicals against Alternaria carthami the causal agent of Alternaria blight of safflower (Carthamus tinctorus L.). African J. of Microbio. Res. 8 (13): 1400-1412.

Wanggikar, A. A., Wagh, S. S., Kuldhar, D. P. and Pawar, D. V. (2014) Effect of fungicides, botanicals and bioagents against purple blotch of onion caused by Alternaria porri. Inter. J. Pl. Prot., 7 (2): 405-410.

\section{How to cite this article:}

Bhosale, R.P., K.D. Navgire, K.A. Rewale and Wahul, S.M. 2018. In vitro Evaluation of Various Bioagents against Detected Seed Mycoflora of Groundnut. Int.J.Curr.Microbiol.App.Sci. 7(10): 1589-1595. doi: https://doi.org/10.20546/ijcmas.2018.710.179 